\title{
BOTULISM IN BRAZIL, 2000-2008: EPIDEMIOLOGY, CLINICAL FINDINGS AND LABORATORIAL DIAGNOSIS
}

Ruth Estela Gravato ROWLANDS(1), Christiane Asturiano RISTORI(1), Giselle Ibette S. Lopez LOPES(1), Ana Maria Ramalho de PAULA(1), Harumi SAKUMA(1), Raquel GRIGALIUNAS(1), Roberto LOPREATO FILHO(1), Dilma Scala GELLI(1), Maria Bernadete de Paula EDUARDO(2) \& Miyoko JAKABI(1)

\begin{abstract}
SUMMARY
Botulism is a rare and potentially lethal illness caused by Clostridium botulinum neurotoxin. We describe the findings of a laboratorial investigation of 117 suspected cases of botulism reported to the surveillance system in Brazil from January 2000 to October 2008. Data on the number and type of samples analyzed, type of toxins identified, reporting of the number of botulism cases and transmission sources are discussed. A total of 193 clinical samples and 81 food samples were analyzed for detection and identification of the botulism neurotoxin. Among the clinical samples, $22(11.4 \%)$ presented the toxin (nine type A, five type AB and eight with an unidentified type); in food samples, eight (9.9\%) were positive for the toxin (five type A, one type AB and two with an unidentified type). Of the 38 cases of suspected botulism in Brazil, 27 were confirmed by a mouse bioassay. Laboratorial botulism diagnosis is an important procedure to elucidate cases, especially food-borne botulism, to confirm clinical diagnosis and to identify toxins in food, helping sanitary control measures.
\end{abstract}

KEYWORDS: Botulism; Botulinum neurotoxin; Clostridium botulinum; Laboratorial diagnosis; Epidemiologic surveillance.

\section{INTRODUCTION}

Botulism is a rare and severe illness that is potentially lethal if not treated rapidly. It is caused by Clostridium botulinum neurotoxin. Four clinical forms of botulism are described: food-borne, adult intestinal, infant and wound. Although rare, iatrogenic and inhalation forms have been described ${ }^{2,8}$. The incubation periods generally range from six hours to 10 days depending on the toxin quantity ingested, but it usually ranges from 18 to 36 hours. The clinical syndrome is characterized by symptoms and neurologic signs that upon onset can be nonspecific (headache, dizziness) before progressing to cranial nerve palsies followed by descending flaccid and symmetric muscle paralysis, which can cause respiratory failure and death. In food-borne botulism, the most common and important form in public health, gastrointestinal manifestations such as nausea, vomit, diarrhea or constipation can also occur at the onset of illness. Food-borne botulism is caused by the ingestion of food contaminated with the preformed toxin ${ }^{1,4,5,7}$. Therapy involves intensive care unit support to the patient to maintain vital conditions, with mechanical ventilation if needed, and administration of equine antitoxin to prevent the progression of neurologic symptoms ${ }^{13}$.

Seven immunologically distinct toxins are produced as a result of C. botulinum spore germination (A, B, C1, D, E, F and G). Types A, $\mathrm{B}, \mathrm{E}$, and more rarely $\mathrm{F}$, are responsible for most human cases ${ }^{12,16}$. In
Brazil, reported cases of botulism were usually caused by toxins A or B and were related to commercially and home canned vegetables fruits or meat and other foods ${ }^{10}$.

Laboratorial diagnosis of botulism is confirmed by the presence of toxin in clinical samples and/or leftovers of food previously consumed by patients. The standard tests employed for the detection and identification of botulinum neurotoxin are mouse toxicity and neutralization bioassay tests. Although other in vitro tests have been developed, none of them presented sensitivity and specificity in comparison to the bioassay, which is considered an efficient tool for toxin detection ${ }^{11,15}$. The Food Microbiology Section at the Adolfo Lutz Institute is the only laboratory in Brazil that has performed botulism diagnosis since 1982. In 2002, it was integrated into the National Laboratories Network for Epidemiologic Surveillance, performing botulism diagnosis in all national territories.

This study reports the findings of a laboratorial investigation of suspected cases of botulism reported to the surveillance system in Brazil from January 2000 to October 2008 that are related to the detection and identification of botulinum toxins.

\section{MATERIAL AND METHODS}

A total of 193 clinical samples (111 serum, 33 gastric contents, 39 


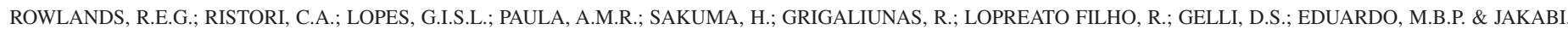
M. - Botulism in Brazil, 2000-2008: epidemiology, clinical findings and laboratorial diagnosis. Rev. Inst. Med. Trop. Sao Paulo, 52(4): 183-6, 2010.

feces, four viscera, three cerebrospinal fluid, one vomit, one wound exudates, one plasma) and 81 food samples from 117 suspected cases of botulism were analyzed in this period by the Food Microbiology Section of Adolfo Lutz Institute. Samples were taken from distinct Brazil states such as Amazonas, Bahia, Ceará, Goiás, Maranhão, Mato Grosso, Mato Grosso do Sul, Minas Gerais, Pará, Paraná, Pernambuco, Rio de Janeiro, Rio Grande do Norte, Rio Grande do Sul and São Paulo.

Diagnosis was made by the mouse bioassay as described by KAUTTER et al. (1992) ${ }^{11}$ and SOLOMON et al. (2001) ${ }^{15}$. Briefly, white Swiss female mice (20-25 g) were used for the assay. Serum and cerebrospinal fluid were directly injected into two mice intraperitoneally; the other samples (gastric contents, feces, viscera, vomit and food) were prepared (toxin extraction), treated and injected into two mice. Mice were observed closely for the first six hours after inoculation and in 3-4 $\mathrm{h}$ intervals thereafter for $96 \mathrm{~h}$. When the bioassay was positive for toxic substances compatible with botulinum neurotoxin, the remaining material was submitted for the determination of toxin type by neutralization of the toxin with specific botulinum antiserum types A, B, E and F. In suspected cases of wound botulism, adult intestinal or infant botulism, samples were initially cultured for detection and isolation of $C$. botulinum and subsequently analyzed by the bioassay.

\section{RESULTS AND DISCUSSION}

A total of 193 clinical samples and 81 food samples obtained from January 2000 to October 2008 were analyzed. Among clinical samples, $22(11.4 \%)$ presented the toxin, consisting of $17(8.8 \%)$ serum, three $(1.5 \%)$ feces and two $(1.0 \%)$ gastric content samples. In food samples, eight $(9.9 \%)$ were positive, consisting of home-canned meat, home pork liver pâté, industrialized canned liver pâté, canned tofu cream (soybean cheese), chicken pie with cheese cream, chicken pastry, chicken pie with peas and heart of palm and home-canned fish. In eight clinical (four serum, three feces and one gastric content) and two food (chicken pastry and home-canned fish) samples, toxin type identification was not possible. Among 117 suspected cases tested by our institution, 27 (23.1\%) were confirmed for botulism, consisting of 18 cases $(66.7 \%)$ caused by type A toxin, five (18.5\%) caused by type A and B and four cases $(14.8 \%)$ by unidentified type (Table 1$)$. Of 38 cases of suspected botulism in Brazil, 27 (71\%) were confirmed by the mouse bioassay and 11 cases $(29 \%)$ by clinical-epidemiologic criteria (compatible clinical symptoms, electroneuromyography and/or epidemiologic links among cases from outbreaks). All samples submitted for cultures of $C$. botulinum were negative.

The case-fatality rate for botulism was high, reaching $34.2 \%$ during the observation period. Botulism is rare, thus many physicians are unfamiliar with the disease. Therefore, patients with botulism can be misdiagnosed as having other illnesses such as Guillain-Barré Syndrome, Miller-Fisher Syndrome and myasthenia gravis, resulting in delays in the administration of botulinum antitoxin and increased mortality. Although botulism is typically rare, fatality can be high if the disease is not treated immediately. The high mortality rate is related to delayed clinical diagnosis, and respiratory failure is a major cause of death. A significant reduction in mortality is observed when patients are treated in hospital units with intensive therapy ${ }^{2}$.

The mouse bioassay is performed in a limited number of public health laboratories. From the time that mice are injected, final results may not be available for 24 or $48 \mathrm{~h}$. Accordingly, all clinical management decisions and initial public health interventions are determined based solely on clinical diagnosis. The only specific treatment for botulism is the administration of botulinum antitoxin. Antitoxin should be given early in the course of illness, ideally $<24 \mathrm{~h}$ after the onset of symptoms, because antitoxin neutralizes only toxin molecules that are unbound to nerve endings ${ }^{14}$.

Laboratorial diagnosis of botulinum neurotoxin has been fundamental to elucidating food-borne botulism, because these results can help to determine the contaminated food source. Although microorganism culture methods can be applied for the isolation of viable cells of $C$. botulinum in food or clinical samples, they are not sufficient to confirm the cause of illness, requiring interpretation of the results related to case definition in the epidemiologic investigation. C. botulinum spores are routinely ingested and excreted by humans without germination, toxin production, or any harm to the person through whom they pass. The exceptions are the small number of infants who develop infant botulism and the handful of adults who develop adult toxemic infectious botulism ${ }^{12}$. The demonstration of C. botulinum in patient stool samples or in cultures of wound material is generally satisfactory for the diagnosis of adult botulism syndromes and is considered definitive for the diagnosis of infant botulism ${ }^{14}$.

This study showed that, as described in the scientific literature, in addition to home-canned meat and vegetables, several other food sources were implicated in outbreaks, including baked dishes containing stuffing, such as pie and pizza. The toxin in these foods was associated with several events of the production process: raw material contaminated with spores of $C$. botulinum, inadequate time/temperature applied to kill spores, destruction of competitive microorganisms and/or elimination of oxygen during cooking/roasting, germination and growth of vegetative cells, and toxin production during storage processes ${ }^{3,6,9,10,13}$.

An outbreak associated with soybean cheese (tofu) was the first described in Brazil $^{9}$ and was related to a commercial product imported from China. In the Unites States, similar cases have been reported that were associated with consumption of fermented tofu ${ }^{6}$. The development of $C$. botulinum and the production of toxin in tofu are propitiated by the neutral $\mathrm{pH}$ of the product, boiling (which creates anaerobic conditions) and the maintenance of room temperature $\left(20-25^{\circ} \mathrm{C}\right)$ before, during or after food preparation. In pâté samples, toxin production could occur due to incorrect handling and maintenance of food and could be due to a lack of nitrite, which is one of the principal measures utilized to control C. botulinum.

In this study, $77.5 \%$ of suspected cases analyzed were negative for botulinum neurotoxin. The findings that were later confirmed by clinicalepidemiologic criteria showed that the principal causes of misdiagnosis were delayed collection and inadequate quantities of samples to perform the bioassay. The remaining negative cases were discharged as botulism. The notification of suspected cases in Brazil has been compulsory since 2001, facilitating the development of epidemiologic and sanitary investigation and implementation of new sanitary measures to control and prevent this illness. Botulism laboratory diagnosis is an important basis for elucidating cases, especially cases of food-borne botulism, confirming the clinical diagnosis and identifying toxins in food, allowing for epidemiologic and sanitary surveillance for sanitary control measures. 


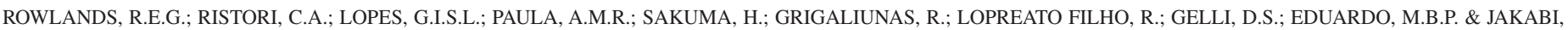
M. - Botulism in Brazil, 2000-2008: epidemiology, clinical findings and laboratorial diagnosis. Rev. Inst. Med. Trop. Sao Paulo, 52(4): 183-6, 2010.

Table 1

Cases of botulism in Brazil, by state of residence, confirmed by laboratorial diagnosis from January 2000 to October 2008

\begin{tabular}{|c|c|c|c|c|c|}
\hline Year & State & $\begin{array}{c}\text { Cases } \\
\text { (Gender })\end{array}$ & $\begin{array}{c}\text { Clinical samples } \\
\text { (confirmed/analyzed) }\end{array}$ & $\begin{array}{c}\text { Food samples } \\
\text { (confirmed/analyzed) }\end{array}$ & $\begin{array}{l}\text { Samples confirmed/identification } \\
\text { of toxin type }\end{array}$ \\
\hline 2001 & São Paulo & $1(\mathrm{M})$ & $2 / 3$ & $0 / 10$ & $\begin{array}{l}\text { Serum and feces/Not enough material for } \\
\text { identification of type }\end{array}$ \\
\hline 2002 & Mato Grosso do Sul & $\begin{array}{l}3(\mathrm{~F}) \\
1(\mathrm{M})\end{array}$ & $0 / 7$ & $1 / 6$ & Home canned meat/Type A \\
\hline 2002 & Ceará & $1(\mathrm{M})$ & $0 / 0$ & $1 / 2$ & Home canned liver pork pâté/Type A \\
\hline 2002 & São Paulo & $1(\mathrm{M})$ & $1 / 3$ & $0 / 0$ & Serum/Type A \\
\hline 2002 & Minas Gerais & $1(\mathrm{M})$ & $2 / 2$ & $0 / 8$ & $\begin{array}{l}\text { Serum/Type A } \\
\text { Feces/Not identified }\end{array}$ \\
\hline 2003 & Bahia & $1(\mathrm{M})$ & $1 / 3$ & $0 / 1$ & Gastric contents/Type A and B \\
\hline 2004 & Pernambuco & $1(\mathrm{M})$ & $1 / 3$ & $0 / 0$ & Serum/Type A and B \\
\hline 2004 & Bahia & $2(\mathrm{M})$ & $2 / 2$ & $0 / 2$ & Serum/Type A \\
\hline 2005 & Minas Gerais & $1(\mathrm{~F})$ & $2 / 3$ & $1 / 1$ & $\begin{array}{l}\text { Serum/Type A } \\
\text { Industrialized liver pâté/Type A }\end{array}$ \\
\hline 2005 & Minas Gerais & $1(\mathrm{~F})$ & $1 / 3$ & $0 / 0$ & Serum/Type A and B \\
\hline 2005 & São Paulo & $\begin{array}{l}3(\mathrm{~F}) \\
1(\mathrm{M})\end{array}$ & $2 / 11$ & $1 / 3$ & $\begin{array}{l}\text { Serum/Not identified } \\
\text { Gastric contents/Not identified } \\
\text { Commercial canned soybean cheese(tofu)/Type A }\end{array}$ \\
\hline 2006 & São Paulo & $1(\mathrm{M})$ & $1 / 1$ & $1 / 2$ & $\begin{array}{l}\text { Serum/Type A } \\
\text { Chicken pie with cream cheese/Type A }\end{array}$ \\
\hline 2006 & Rio Grande do Norte & $1(\mathrm{~F})$ & $1 / 2$ & $0 / 1$ & Serum/Type A and B \\
\hline 2006 & Ceará & $3(\mathrm{~F})$ & $2 / 3$ & $1 / 1$ & $\begin{array}{l}\text { Serum/Type A } \\
\text { Chicken pastry/Not identified }\end{array}$ \\
\hline 2007 & São Paulo & $1(\mathrm{M})$ & $1 / 1$ & $1 / 1$ & $\begin{array}{l}\text { Serum/Type A and B } \\
\text { Chicken pie with peas and hearts of palm/Type } \\
\text { A and B }\end{array}$ \\
\hline 2007 & São Paulo & $1(\mathrm{M})$ & $1 / 2$ & $0 / 0$ & Serum/Not identified \\
\hline 2007 & São Paulo & $1(\mathrm{~F})$ & $1 / 3$ & $1 / 2$ & $\begin{array}{l}\text { Serum/Not identified } \\
\text { Home comfit of fish/Not identified }\end{array}$ \\
\hline 2008 & São Paulo & $1(\mathrm{M})$ & $1 / 4$ & $0 / 1$ & Feces/Not identified \\
\hline
\end{tabular}

F- female; M- male.

Effective treatment depends on supportive intensive care and rapid administration of botulinum antitoxin based on clinical presentation, because laboratory diagnosis is time-consuming.

\section{RESUMO}

\section{Botulismo no Brasil, 2000-2008: epidemiologia, achados clínicos e diagnóstico laboratorial}

Botulismo é uma doença rara e potencialmente letal, resultante da ação de uma neurotoxina produzida pelo Clostridium botulinum. No presente estudo, estão descritos os resultados da investigação laboratorial de 117 casos suspeitos de botulismo notificados ao sistema de vigilância, ocorridos no Brasil no período de janeiro de 2000 a outubro de 2008.
Os dados obtidos sobre as fontes de transmissão, os tipos de toxina identificados e de amostras analisadas serão discutidos. Foram analisadas 193 amostras clínicas e 81 amostras de alimentos para detecção e identificação de neurotoxina botulínica. Entre as amostras clínicas, 22 $(11,4 \%)$ amostras apresentaram resultado positivo para toxina (nove do tipo $\mathrm{A}$, cinco do tipo $\mathrm{AB}$ e em oito o tipo não foi identificado) e entre as amostras de alimentos, oito $(9,9 \%$ ) foram positivas (cinco do tipo A, uma do tipo $\mathrm{AB}$ e em duas o tipo não foi identificado). Dos 38 casos considerados positivos para botulismo, 27 foram confirmados pelo bioensaio em camundongo. O diagnóstico laboratorial de botulismo é importante para elucidação dos casos, principalmente de botulismo alimentar, para confirmação dos diagnósticos clínicos e identificação das toxinas nos alimentos, provendo subsídios para as medidas de controle sanitário. 
ROWLANDS, R.E.G.; RISTORI, C.A.; LOPES, G.I.S.L.; PAULA, A.M.R.; SAKUMA, H.; GRIGALIUNAS, R.; LOPREATO FILHO, R.; GELLI, D.S.; EDUARDO, M.B.P. \& JAKABI, M. - Botulism in Brazil, 2000-2008: epidemiology, clinical findings and laboratorial diagnosis. Rev. Inst. Med. Trop. Sao Paulo, 52(4): 183-6, 2010.

\section{ACKNOWLEDGMENTS}

We acknowledge the colleagues of Lab Animal Production Facilities of Adolfo Lutz Institute for providing Swiss Webster mice for the bioassay. We also thank Letícia Maria de Campos for critically reviewing this article, and Márcia C. Tauil and Greice Madeleine I. do Carmo from National Secretary of Health Surveillance (SVS)/Brazil Ministry of Health (MS) and Lúcia Helena Berto of the General Coordination of Health Public Laboratories (CGLAB) for information on the number of botulism cases and deaths in Brazil.

\section{REFERENCES}

1. Angulo FJ, St. Louis ME. Botulism. In: Centers for Disease Control and Prevention (CDC). Bacterial infections of humans: epidemiology and control. Atlanta: The Centers; 1999. p. 139-53.

2. Arnon SS, Schechter R, Inglesby TV, Henderson DA, Bartlett JG, Ascher, M, et al. Botulinum toxin as a biological weapon: medical and public health management. JAMA. 2001;285:1059-70.

3. Borges Filho TS, Santos SJ, Silveira MC, Cardoso P, Perandones CA, Moreno M, et al. Botulismo associado a alimentos comerciais assados doados, município de São Vicente, SP - Junho de 2007. Bol Epidemiol Paulista. 2007;4(46):1-6. Available from: http://www.cve.saude.sp.gov.br/agencia/bepa46_botu.htm

4. Brasil. Ministério da Saúde. Secretaria de Vigilância em Saúde. Departamento de Vigilância Epidemiológica. Manual integrado de vigilância epidemiológica do botulismo. Brasília: Ministério da Saúde; 2006. 88 p. (Série A. Normas e Manuais Técnicos).

5. Cecchini E, Ayala SEG, Coscina Neto AL, Ferrareto AMC. Botulismo. In: Veronesi R, Focaccia R, editores. Tratado de infectologia. São Paulo: Atheneu; 1997. p. 565-74.

6. Centers for Disease Control and Prevention. Brief Report: foodborne botulism from home-prepared fermented tofu - California, 2006. MMWR. 2007;56:96-7. Available from: http://www.cdc.gov/mmwr/preview/mmwrhtml/mm5605a2.htm (Acessed May 11, 2008).
7. Cherington M. Botulism: update and review. Semin Neurol. 2004;24:155-63.

8. Coban A, Matur Z, Hanagasi HA, Parman Y. Iatrogenic botulism after botulinum toxin type A injections. Clin Neuropharmacol. 2010;33:158-60.

9. Coordenadoria de Controle de Doenças. Centro de Vigilância Epidemiológica. Divisão de Doenças de Transmissão Hídrica e Alimentar. Investigação de surto de botulismo associado a tofu (queijo de soja), no município de São Paulo, dezembro de 2005 Bol Epidemiol Paulista. 2006;3:10-4. Available from: http://www.cve.saude.sp.gov. br/agencia/bepa25_botu.htm (Acessed May 11, 2008).

10. Eduardo MBP, Madalosso G, Paiva OR, Brito SN, Araújo EC, Bandeira CRS, et al. Botulismo tipo A e B causado por torta comercial de frango com palmito e ervilhas no Município de São Paulo, SP - Janeiro de 2007. Bol Epidemiol. 2007;4:1-7. Available from: http://www.cve.saude.sp.gov.br/agencia/bepa38_botu.htm (Acessed Jan 05, 2008).

11. Kautter DA, Solomon HM, Lake DE, Bernard DT, Mills DC. Clostridium botulinum and its toxins. In: Vanderzant C, Splittstoesser DF, editors. Compendium of methods for the microbiological examination of foods. $3^{\text {rd }}$ ed. Washington: American Public Health Association; 1992. p. 605-21.

12. Lindström M, Korkeala H. Laboratory diagnostic of botulism. Clin Microbiol Rev. 2006;19:298-314.

13. Sobel J, Tucker N, Sulka A, McLaughlin J, Maslanka S. Foodborne botulism in the United States, 1990-2000. Emerg Infect Dis. 2004;10:1606-11.

14. Sobel J. Botulism. Clin Infect Dis. 2005;41:1167-73.

15. Solomon HM, Johnson EA, Bernard DT, Arnon SS, Ferreira JL. Clostridium botulinum and its toxins. In: Downes FP, Ito K, editors. Compendium of methods for the microbiological examination of foods. $4^{\text {th }}$ ed. Washington: American Public Health Association; 2001. p. 317-24

16. Woodruff BA, Griffin PM, McCroskey LM, Smart JF, Wainwright RB, Bryant RG, et al. Clinical and laboratory comparison of botulism from toxin types A, B, and E in the United States, 1975-1988. J Infect Dis. 1992;166:1281-86.

Received: 1 September 2009

Accepted: 24 June 2010 